\title{
子どものための物理的環境とは何か モンテッソーリ教育の場合
}

\author{
高橋 節子（setsuko@pc.highway.ne.jp）
}

[お茶の水女子大学]

\begin{abstract}
What is a child-friendly educational environment?: A lesson from the Children's Houses of Maria Montessori Setsuko Takahashi

Graduate School of Humanities and Sciences, Ochanomizu University, Japan
\end{abstract}

\begin{abstract}
This study aims to specify the essential nature of a child-friendly educational environment through an analysis of the Children's Houses for 3- to 6-year-old children planned by Maria Montessori whose philosophy and method have spread all over the world. Based on her theory of how children grow and develop, Montessori designed an educational method along with a unique physical environment in which to put it into practice. In the present study, an intensive content analysis of 12 Montessori's books, consisting of her own writings and dictations of her own lectures, was conducted and revealed: (1) Montessori's grand theory of child development governed her educational method and its physical environment which was essentially planned to evoke and support children's competence and autonomy, (2) The 8 properties of the physical environment, which were indispensable to the education of young children, were identified, e.g., the environment must (a) be attuned to children's body size and their physical and cognitive abilities; (b) be responsive to children's behavior; and (c) activate children's spontaneous activities, (3) These properties were surely embodied in the physical environment in all of the Montessori Children's Houses. What we can learn from Montessori, now and for the future, is discussed.
\end{abstract}

\section{Key words}

Montessori education, physical environment, child-friendly, child development, spontaneous activity

\section{1. 問題}

マリア・モンテッソーリ（Maria Montessori, 1870-1952) により始められた幼児教育法であるモンテッソーリ教育 は、物理的環境に特徴があることで知られている。その 物理的環境としては、モンテッソーリが考案した教具が 広くなじみがあるだろう。しかし、彼女自身は、教具に とどまらず、子どもが自由に選択し、使用するもの全体 を考慮するべき物理的環境であるとしており、建築、設 備、家具、道具に関して、様々な具体的な提案をしている。 物理的環境の特徵としては、子どもの体格に合わせたサ イズにすることが注目されているが、実際にはそれにと じまらず、多様な性質を持っている。

モンテッソーリは自身の教育施設である「子どもの 家」(イタリア語 : Casa dei Bambini, 英語 : the Children’s House）は、自らの子ども観・発達観および教育の原則を 具体化し、子どもの自己活動と自律的な発達を可能にす る施設であることを示唆している。さらに、「子どもの家」 のプラン・構成・内容は子どもが発達の段階に応じて必 要とするものに基づいているともしている（モンテッソー リ，1993,pp. 120-124）。しかし、筆者の検討した限りでは、 モンテッソーリの思想が、どのように物理的環境に反映
されているのかを、体系的に明確にした研究は見当たら ない。

そこで本研究では、モンテッソーリ自身の著作の分析に より、なぜモンテッソーリは物理的環境を重視したのか、 「子どもの家」の物理的環境はモンテッソーリの子ども観・ 発達観、教育の原則にどのように基づいて設定されたも のであるかを体系的に明らかにしたい。加えて、これま でほとんど分析されてこなかった教具以外の物理的環境 （建築、設備、家具、道具）の性質と具体的な特徵につい て明らかにする。

\section{1 モンテッソーリ教育とは}

モンテッソーリ教育は、20 世紀初頭にイタリアの教育 者マリア・モンテッソーリによって始められた。モンテッ ソーリは初め、大学で医学を学び、1896 年にローマ大学 初の女性の医学博士となった（早田, 2003)。卒業後、大 学付属の精神科クリニックに職を得ると、知的障がい児 に関心を持つようになった。すると、彼女は、知的障が い児の問題とは、医学ではなく、教育の問題であるとと らえ、次第に関心を医学から、教育へと移行させていっ た。障がい児教育の先駆者である Itard（1774-1838）や Séguin（1812-1880）の思想や教育方法、さらに実験心理 学などを学んだモンテッソーリは、障がい児教育を実践 し、大きな成果を上げた。この経験を踏まえ、1907 年に ローマに「子どもの家」を開設し、主としていわゆる健 
常な $3 \sim 6$ 歳児を対象に幼児教育を始めたのである。こ れが評判を呼ぶと、彼女はこの教育実践を著書Il metodo della pedagogia scientifica applicato all'educazione infantile nelle case dei bambini (Montessori, 1909) にまとめ、モン テッソーリ教育は広く知られるようになった。その後、 さらなる著作や講演などにより、モンテッソーリ教育は イタリア国内にとどまらず国際的に普及し、現在でも日 本をはじめ、世界各地で実践され続けている（Standing, 1957/1975/1998)。

なお、モンテッソーリ教育は19 世紀末より览童中 心の教育を求めた新教育運動のひとつに位置付けられ る（Mooney, 2000)。米国でこの運動の中心となったのは Dewey（1859-1952）であり、同じく児童中心の子ども観 を主張した同時代の代表的な研究者としては Piaget (18961980）やVygotsky（1896-1934）が挙げられる。すなわち、 モンテッソーリ教育と「子どもの家」は、この児童中心 主義の時代精神を具体化したものだともいえる。

\section{2 モンテッソーリ教育の環境に関する先行研究}

本論文は、モンテッソーリの思想と教具以外の物理的 環境（建築、設備、家具、道具）との関連について分析 することを目的とするため、先行研究についてもこの観 点から検討した。

まず、教育学では、子どもが使うという観点からモン テッソーリが理想としたイスの特徵を論じ、子どもの自 発的な活動と環境の特徴を考察した東谷 (2007) の研究 がある。この研究は興味深いものの、モンテッソーリの 教育思想全体と物理的環境との関連を体系づけ、明らか にするまでには至っていない。Peller（1978/1996）は、自 身が「子どもの家」を建築家と協働して設計した経験に 基づき、望ましいモンテッソーリ教育のための幼児教育 施設のあり方を提案している。Burke \& Grosvenor (2008) は英国を中心に、ヨーロッパの幼児教育の進展とそれに 伴う校舎、教室、家具などの物理的環境の変化を概観し ている。Burkeらは、20世紀初頭に一般的であった、床 に固定された机とイスは、子どもを主体とする教育には ふさわしくないと異議を唱えた教育者として、モンテッ ソーリを位置づけている。しかし、物理的環境の変遷の 中に位置づけるにとじまり、教育思想と物理的環境の関 連は十分に分析していない。

その他の教育学の研究では、モンテッソーリの教育理 念における「環境」について哲学的に考察した研究が中 心である。例えば、甲斐 $(1985 ; 1995 ; 1997)$ はモンテッソー リの思想の核として独特の生命観があり、彼女の生命観 は生物学的な生命体から宇宙の生命体に広がり、それに 対応する環境があると解釈する。人間は生物学的な生命 体として発達の計画を持つが、それに基づいて発達する ためには、人間の環境を整えなければならないと指摘し ている。

建築学での研究では、Dudek（2000）が幼児教育史に沿 い、園舎や家具などの物理的環境がどのように変化した かを分析している。子ども中心の教育理念の進展ととも
に、子どもの自律的な活動を身体的にも可能にするため、 19 世紀末から 20 世紀初頭に、子どもが自由に動き回れ るように、固定された机が廃止され、子どもの体格に合 わせた物理的環境が実現されるようになったことを指摘 した。そして、このような物理的環境を実現した教育者 としてモンテッソーリを位置付けている。しかし、Dudek は歴史的に概観することを目的としたためか、各教育法 と物理的環境との関連ついての分析が十分にされている とは言えない。一方、わが国の建築学の研究（神成・初見, 1984; 長沢・深堀, 1988; 天満・菊地, 2004）では、モンテッ ソーリ幼稚園をそれぞれ数か所取り上げ、現地での調查・ 観察によって、園舎内での部屋の配置・保育室内の物の 配置と園児の探索活動・園児同士の交流との関連などを 分析している。これらは、実際の園における物理的環境 と子どもの行動との関連を検討するにとどまり、教育思 想と物理的環境との関連には特に注目してはいない。

このように、筆者が検討した限りでは、モンテッソー リ教育の教育思想と物理的環境との関連を十分に分析し た研究や、物理的環境の特徵を体系的にとらえ、詳細に 分析した先行研究は見当たらなかった。

\section{3 本研究の目的}

そこで、本研究ではモンテッソーリ自身の著作の記述 内容を分析し、次の 3 点を明らかにすることを目的とした。

（1）モンテッソーリの子ども観・発達観及び教育の原則、 人的環境と物理的環境とはどのようなものか、その 全体像を明らかにする。

（2）物理的環境がどのような性質を持つのかを詳細に検 討する。さらに、これまでほとんど体系的に分析さ れることがなかった教具以外の物理的環境、すなわ ち園舎、庭、保育室、設備、家具、道具の特徵を具 体的に明らかにする。

（3）これらをもとに、なぜモンテッソーリは物理的環境 を重視したのか、彼女の子ども観・発達観や教育の 原則が物理的環境にどのように反映されているかを 考察する。

\section{2. 研究の方法}

\section{1 内容分析したモンテッソーリの著作}

本研究では、上述の 3 点を明らかにするため、モンテッ ソーリ自身の著作 12 点を分析の対象とし、記述内容を分 析した。なお、本研究で分析したのは、物理的環境に最 も特色がある、主として $3 \sim 6$ 歳児を対象とするモンテッ ソーリ教育である。

分析の対象としたモンテッソーリの著作 12 点の日本語 及び英語またはドイツ語の題名を表 1 に示した。また、 12 著作の実際に分析に用いた文献の情報については、文 末の付録に記載した。

分析に当たっては、まず、モンテッソーリによるモン テッソーリ教育に関する最初の著作であり、モンテッソー リ教育が広く普及する契機となった『モンテッソーリ・ 
メソッド』（表 1 の文献(1)）を分析対象とした。次に、モ ンテッソーリの 3 大著作とされる（鼓，1968） 3 冊『幼児 の秘密』、『創造する子供』、『子どもの発見』(2)〜 (4))、 それにモンテッソーリ自身が出版した最後の著作『人間 の形成について』（5)）を分析対象とし、以上の 5 点を初 出年順に(1)〜 (5)とした。これに本研究の目的である物理 的環境に関する記述が多い著作 7 点（6)〜 (12)）を分析対 象に加え、この 7 点についても初出年順に(6)〜12)とした。

なお、表 1 に示したように、分析した著作には、モン テッソーリの執筆による著作、新聞の連載記事、雑誌等 に掲載の小論に加えて、モンテッソーリが行った講義・ 講演の記録を収録したものも含まれる。そのため、初出 の時期が明確でないものもある。しかも、モンテッソー リ教育は世界各国で普及したため、彼女の母国語である イタリア語版が原書とは限らず、したがって、日本語翻 訳版も様々な言語から訳出され、重訳も見られる。そこ で、分析の正確さを高めるために、内容分析にあたって は、表 1 に示したように主として分析した版（表 1 の○印） に加え、異なる言語の版を少なくとも 1 点は参照した（表 1 の○印)。特に最も重要であると考えられた 4 著作（1) 〜4) に関しては必要に応じて、主とする版に加え、異 なる言語の版 2 点を参照した。

\section{2 著作の分析方法}

前述のように選択したモンテッソーリの 12 著作から、 子ども観・発達観及び教育の原則、人的環境、物理的環 境に関連する記述をすべて抜き出し、1つの内容を 1 枚の カードに記すという方法でカードを作成した。なお、本 研究では教具以外の物理的環境を体系的に明らかにする ことを目的としている。そのため、教具はそれの教育に おける位置や性質に関する記述についてはカード化した が、個々の教具のねらいや使用方法については、本研究 の目的から外れるためにカード化しなかった。

こうして作成したカードは合計 1,151 枚となった。この カードの記述を 1 枚ずっ吟味し、同じあるいは類似した 内容のカードをまとめるという方法で整理し、有効な力 テゴリーを決めながら分類を繰り返し、カテゴリー間の 関連を考えて体系づけるという方法で分析した。

\section{3. 分析の結果}

モンテッソーリの著作の内容分析の結果は図 1 のよう にまとめられた。

図 1 に見るように、モンテッソーリは、子どもは発達 する可能性を持つという「子ども観・発達観」を持って いることが明らかになった。そして、この「子ども観・ 発達観」に基づいて、子どもが発達のために必要とする

表 1 : 本論文で分析したモンテッソーリの著作

\begin{tabular}{|c|c|c|c|c|c|c|}
\hline \multirow{2}{*}{ 著作の題名 } & \multirow{2}{*}{ 初出年 ${ }^{a)}$} & \multirow{2}{*}{ 初出の形式 } & \multicolumn{4}{|c|}{ 分析した言語版 } \\
\hline & & & 日本語版 & 英語版 & 伊語版 & 独語版 \\
\hline $\begin{array}{l}\text { (1) モンテッソーリ・メソッド } \\
\text { The Montessori method. }\end{array}$ & 1909 & 書き下ろし & $\bullet$ & $\bigcirc$ & $\bigcirc$ & \\
\hline $\begin{array}{l}\text { (2)幼児の秘密* } \\
\text { The secret of childhood. }\end{array}$ & $1936^{b)}$ & 講演 & ○ & $\bigcirc$ & $\bigcirc$ & \\
\hline $\begin{array}{l}\text { (3)創造する子供* } \\
\text { The absorbent mind. }\end{array}$ & 1947 & 養成コースの講義 c) & 0 & $\bigcirc$ & $\bigcirc$ & \\
\hline $\begin{array}{l}\text { (4)子どもの発見* } \\
\text { The discovery of the child. }\end{array}$ & 1948 & (1)の改訂 & - & $\bigcirc$ & $\bigcirc$ & \\
\hline $\begin{array}{l}\text { (5)人間の形成について } \\
\text { The formation of man. }\end{array}$ & 1949 & おそらく書き下ろし & - & $\bigcirc$ & & \\
\hline $\begin{array}{l}\text { (6)私のハンドブック } \\
\text { Dr. Montessori's own handbook. }\end{array}$ & 1914 & 書き下ろし & ○ & $\bigcirc$ & & \\
\hline $\begin{array}{l}\text { (7)モンテッソーリ教育の実践理論 } \\
\text { The California lectures. }\end{array}$ & 1915 & 講演・新聞連載 & $\bigcirc$ & 0 & & \\
\hline $\begin{array}{l}\text { (8)幼児と家庭 } \\
\text { The child in the family. }\end{array}$ & 1923 & 講演 & ○ & $\bigcirc$ & & \\
\hline $\begin{array}{l}\text { (9)モンテッソーリの教育法 : 基礎理論 } \\
\text { Grundlagen meiner Pädagogik. }\end{array}$ & 1926-34 & 雑誌等掲載の小論 & ○ & & & $\bigcirc$ \\
\hline $\begin{array}{l}\text { (10)子どもと学校の危機 } \\
\text { The child, society and the world. }\end{array}$ & 1930 頃 -51 & 養成コースの講義 ${ }^{c}$ 等 & - & $\bigcirc$ & & \\
\hline $\begin{array}{l}\text { (11)モンテッソーリの教育 : ○歳〜六歳まで } \\
\text { Education for a new world. }\end{array}$ & 1936-39 & 講演 & 0 & $\bigcirc$ & & \\
\hline $\begin{array}{l}\text { (12)子供の何を知るべきか } \\
\text { What you should know about your child. }\end{array}$ & 1948 & 養成コースの講義 ${ }^{c}$ & $\odot$ & $\bigcirc$ & & \\
\hline
\end{tabular}

(凡例) ${ }^{*}$ : モンテッソーリの 3 大著作、: 主として分析、○ : 分析時に参照

(注) : ${ }^{a)}$ 書き下ろしの著作は原書の初版出版年、講演及び講義は行った年、雑誌の小論及び新聞の連載は掲載年を初出とした。

b) 講演時期が不明のため、本書は原書の初版の出版年を初出とした。

c) モンテッソーリ教育の教師養成のためのコースでの講義。 
環境との相互交涉を存分に行えるように「教育の原則」 を考え、この原則を実現するために教育環境一「人的環 境」と「物理的環境」一のあり方を提案した、と整理す ることが妥当であると考えられた。なお、モンテッソー リ教育の理念と環境は、抽象的に構築されたものではな く、モンテッソーリ自身の教育実践や子どもの観察など の事実に基づき形成されたことも特徴であった。以下で は、この分析の結果を示した図 1 に沿って述べていく。

なお、本稿の分析結果の記述では、その根拠を明確に するために、それぞれの記述の後の（）内に、それが 主として記述されている文献番号とページを明示した。 具体的には、主な記述箇所を表 1 に示した著作番号(1) 12)で示し、次に記述箇所のページを記した。各言語版は 日本語版はJ、英語版は E、イタリア語版は I、ドイツ語 版は G という記号で表した。前述のように分析の正確さ を高めるため、異なる言語の版を参照した場合には、異 なる言語版の記述箇所も合わせて示している。例えば、 記述箇所が『子どもの発見』の日本語版のp. 125、英語 版のp. 104、イタリア語版の p. 115 の場合は、(4) J125, E104，I115）と記述した。

\section{1 子ども観・発達観}

（1）子どもは発達する可能性を持つ

モンテッソーリの子ども観・発達観の根本にあるの は、子どもが持つ「発達する可能性」である。モンテッ ソーリは人間の子どもは自身を取り巻く環境と相互交涉 し、あらゆることを吸収して、自らの精神を形成し、発
達する可能性を持つと考えたのである（2）J122, E103-104， I138; (3) J26, E25, I 25-26; (3) J57, E58)。例えば、言語や習 慣なども、両親や自分の属する民族から、生まれながら に受け継ぐものではなく、環境との交渉により、子ども が獲得するとしたのである (3) J62-64, E61-64, I63-64)。

また、モンテッソーリは、子どもは文化を吸収し発達 する可能性を持つとも述べている（3) J6-7, E7-8, I5-6)。 環境を吸収して精神を形成することで、子どもは自分が 属する社会の文化に適応していくとした（3) J57, E58; (3) $\mathrm{J} 66, \mathrm{E} 65)$ 。

\section{（2）子どもは環境との相互交渉によって発達する}

モンテッソーリは、子どもは「発達する可能性」を持 つが、環境との相互交渉により環境からあらゆるものを 吸収することで、はじめて発達が実現するとした（2) J122, E103-104, I138; (3) J26, E25)。すなわち、発達には環 境との相互交渉が欠かせないというのである。

モンテッソーリは、 0 〜 歳児における環境との相互 交涉による発達の段階を 2 期に区分した（3) J162-163, E165-166; (11) J105-107, E49-50)。第 1 期は 0 〜 3 歳である。 この時期の子どもは身体的には未発達で活発ではないが、 誕生時から精神は活発に活動しており（10) J45, E28; (12) J7, E4)、目や耳などの感覚器官を駆使して、能動的に環境か らあらゆる印象を取り入れ、自らの精神を形成する（11) J68, E30)。第2期の $3 \sim 6$ 歳になると、身体的器官が成熟し、 機能するようになる。子どもは環境の中を自由に動き回 り、手を使った活動が増え、意識的に、そして活発に環

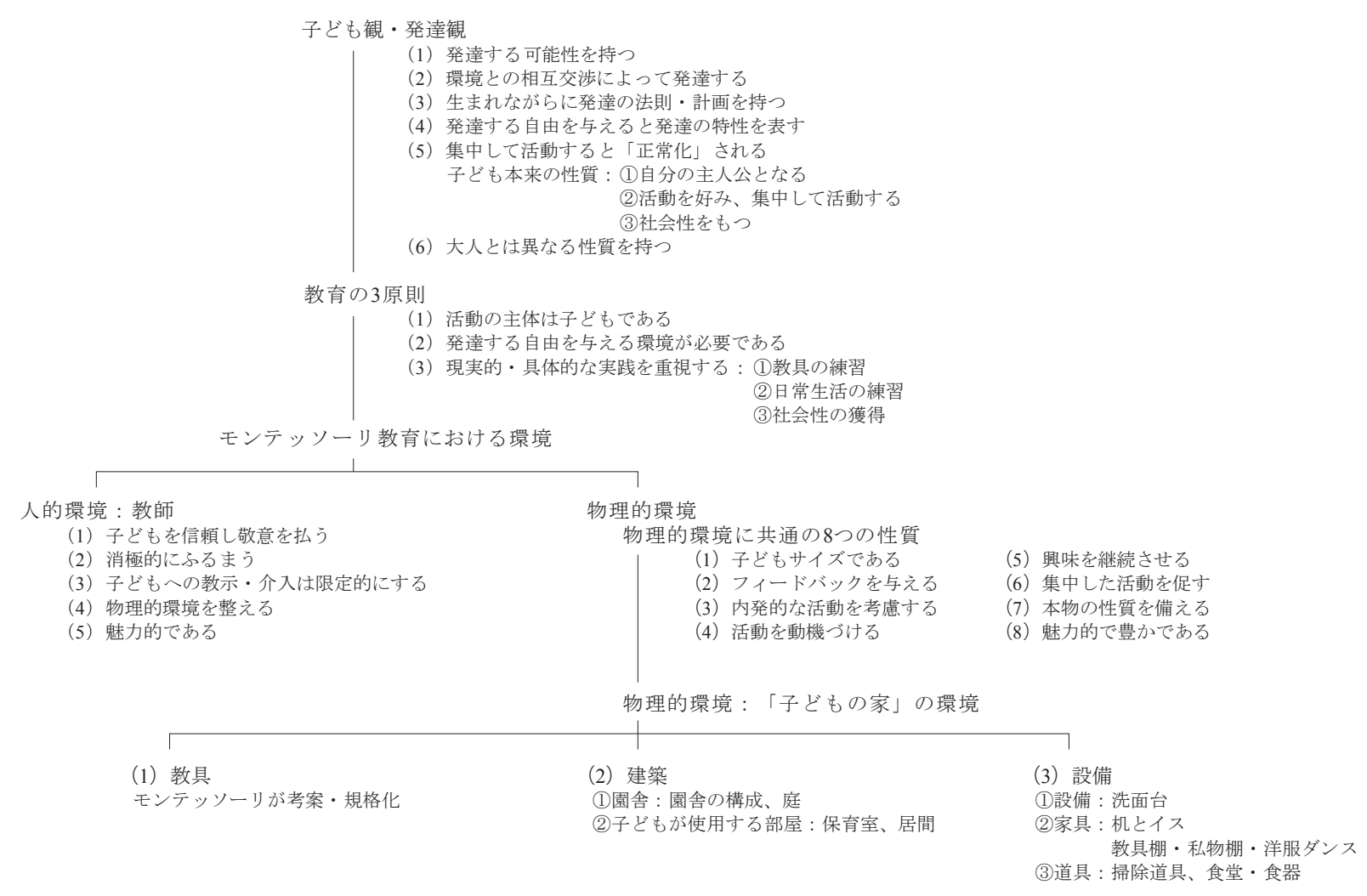

図 1 : モンテッソーリ教育の理念と人的及び物理的環境 
境と交渉し、精神的にも身体的にも発達するとされた（3) $\mathrm{J} 164, \mathrm{E} 168)$ 。第 2 期は、第 1 期に獲得したものを完全に する仕上げの時期でもあり、そのよい例が言語であると いう。子どもはすでに 2 歳半頃から言語を使用するよう になるが、第 2 期にさらに語彙を増やし、発音を完成させ、 言語を豊かにするとした（3) J164, E167）。

\section{（3）子どもは生まれながらに発達の法則・計画を持つ}

「発達する可能性」を持つ子どもは、生まれながらに 発達の法則・計画を持つとした。モンテッソーリはこの 発達の法則・計画（laws, schedule, plan, program）を「自 然が定める法則」(natural laws) とした（3) J212, E218）。 そして、どのような順番で、何を獲得するかという、生 まれながらに定められた発達の計画に基づき、様々な発 達の敏感期（sensitive periods）が現れるとした（12) J23， E15)。

敏感期とは、発達の計画に基づいて周期的に現れる、 特定の能力を獲得するために最適な期間のことであり、 その能力はこの限られた期間に最もよく発達する（2) J50-55, E37-41)。例えば、言語の敏感期では、子どもは 単語だけではなく、細かい文法も一緒に習得する。そして、 発達の計画が目指した通りに言語を獲得すると、言語の 敏感期は終わり、新たな別の能力を獲得するための敏感 期が始まるとした。

また、モンテッソーリは「自然は厳格な親方」（La Natura è una maestra severa) とも表現 し ( (2) J228-229, E197, I276)、生まれながらに持つ発達の法則・計画は早 めることも、遅らせることもできず、子どもは忠実にこ の法則・計画に従い、発達するとした（2) J225-226, E194195)。つまり、子どもは生まれながらに持つ発達の法則・ 計画に忠実に従い、次々に現れる敏感期に基づき、多様 な能力を獲得するために環境との相互交涉を行い、発達 するとしたのである。

（4）子どもに発達する自由を与えると発達の特性を表す モンテッソーリは、自律的活動を可能にする環境にお いてでなければ、子どもは自分自身を表現したり、自分 が必要とすることを表すことをせずに、隠し、抑圧して しまうとした（4)J60, E46, I50-51）。ここまで述べてきた ように、子どもは発達の法則・計画に基づき、環境と相 互交渉することで発達するとされ、これは子どもの発達 の特性だと言える。したがって、子どもに発達に必要な 自律的活動を可能にする環境、すなわち、発達する自由 を与えれば、子どもは発達の特性を遺憾なく発揮すると いうことである（10) J10-11, E5-6）。

（5）子どもは集中して活動すると「正常化」される

当時、子どもは良い性質（好奇心旺盛、想像力豊か、 お話し好き、人なつこいなど）や悪い性質（移り気、だ らしなさ、乱暴、頑固、不従順など）を持つと考えられ ていたという。これに対してモンテッソーリは、子ども が生まれながらに持つ発達の法則・計画に従い、発達の
ために内発的に必要とする活動を集中して行い、環境と 相互交涉すると、それまでの良い性質も悪い性質も全て 消え、まるで「新しい子」（a new child）が現れるように、 異なる性質を見せるようになるとした（3) J196-199, E201204, I200-203)。このような状態は階層や人種、文化の別 なく、どの子どもにも必ず観察されたとモンテッソーリ は主張する (3) J199, E204)。モンテッソーリは、これま で子どもの性質と考えられていた良い性質も悪い性質も、 本来の子どもの性質を覆い隠していたものにすぎないと した（2) J180, E154; (5) J49, E33)。すなわち、「新しい子」 こそが、適切な環境の中で妨げられることなく、生まれ ながらに持つ発達の法則・計画に従い発達した子どもが 見せる、本来の子どもの姿であると考えたのである（3) J198, E203, I202)。

モンテッソーリは、子どもがこの本来の性質を持つに いたることを「正常化」(normalization) と呼び、この「正 常化」を発達の出発点だとした（5) J50, E34）。この「正 常化」した子どもが見せる子ども本来の性質は、次の 3 点にまとめられる（3) J201, E206-207）。

(1) 自分の主人公となる

子どもは自分の主人公となることができる、すなわち、 子どもは自分で考え、判断し、行動することができる（3) $\mathrm{J} 211, \mathrm{E} 217$; (7) E368)。具体的な特徴は次の 3 点にまとめら れる (2) J200-202, E170-173; (3) J254, E260)。a. 自分の行 動をコントロールできる。 b. 感情や衝動をコントロール し、常に安定し、落ち着いた状態にある。c. 自分の意志 だけではなく、集団の規律や他者の意志にしたがい、従 順に行動できる。

(2)活動を好み、集中して活動する

子どもは常に活動したいと願っており、発達のために 必要な活動を自ら選択し、疲れることなく、喜びを感じ ながら活動する。子どもは 1 つの活動に没頭し、集中し て活動できる（3) J197, E202; (11) J112-113, E52-53)。

(3) 社会性を持つ

子どもは他者に関心を持ち、交涉し、共感しあい、協 力し合う。子どもは優れた社会性を持ち、あらゆる場に 容易に適応し、他者と交涉できる。特に、クラス内では 競争や痆妬するのではなく、互いに尊敬し合う（3）J269270, E272-273; (10) J35-38, E21-23)。

\section{（6）子どもは大人とは異なる性質を持つ}

モンテッソーリは、子どもは社会的な役割を果たさな いために 1 人の人間として尊重されることがなく、まる で大人の所有物のように扱われ、尊㛜を無視され、従属 させられてきたと指摘した（2) J223-224, E192-193; (8) J68,E4）。しかし、モンテッソーリはここまで述べてきたよ うに、子どもは精神を形成し発達するために、自らの発 達の法則・計画に基づき、自律的に活動し、環境と相互 交渉すると考えたのである。子どもの活動は必ずしも社 会的、あるいは生産的な活動ではないが、発達のために は欠くことのできない活動であり、子どもが社会的役割 を果たさないのは、大人と比べて劣っているからではな 
く、大人とは性質の異なる活動をしているからだという。 つまり、モンテッソーリは、子どもは大人とは異なる発 達の段階にあり、そのために異なる性質を持つとしたの である（9) J8-9, D9）。

同時に、モンテッソーリが強く主張したのは、子ども も独立した人格であり、大人と同様にひとりの人間とし て尊重されるべきだということである (2) J130, E111; 8) J38-39, E20-21)。モンテッソーリは1915 年には早くも、 子どもの人権とそれに関連する法整備の必要性について 言及している（2) J242, E215; (7) J57-58, E28; (10) J132-134， E81-82)。国際連盟が子どもの権利に関する最初の国際的 宣言「子どもの権利に関するジュネーヴ宣言」を採択し たのは 1924 年であり（中野・小笠，1996）、モンテッソー リは子どもの人権に目を向けた先駆者の 1 人であったこ とが注目される。

\section{2 教育の 3 原則}

モンテッソーリは上述の「子ども観・発達観」を基礎 として、子どもが生まれながらに持つ発達の法則・計画 に従って発達できるように、環境と子どもの自律的な相 互交渉を尊重するため、次の 3 点の「教育の原則」をた てたと整理できた。

（1）活動の主体は子どもである

モンテッソーリは、子どもが生まれながらに持つ発達 の法則・計画に基づき、発達のために必要な環境との相 互交渉ができるように、子どもの自律的活動を尊重した。 したがって、モンテッソーリ教育における活動の主体は 子どもであるとした（2) J131, E111, I148)。それぞれの子 ごもが自ら活動を選び (2) J142, E121; (11) J132, E61)、子 ども自身が好む場所で活動する自由が与えられた（4) J117-118, E96; (7) E364)。そのため、モンテッソーリ教育 では個別活動が中心であった（9) J35, D25）。

\section{（2）発達する自由を与える環境が必要である}

モンテッソーリは、子どもに発達する自由を与えなけ れば、すなわち、自律的活動を可能にする環境において でなければ、子どもは発達の特性を表さないとした。従 来の教育者は、適切な環境を与えることが発達にとって 重要であるということに、関心を払わなかったと言う。 しかし、モンテッソーリは、環境は子どもの活発な活動 に直接関連し、教育にとって最も重要なものであると述 べている (4) J60, E46, I50-51)。したがって、子どもの自 律的活動の障害となるものを最小にし、活動する自由が 最大となるように環境を整えることが大切であるとした。

モンテッソーリは“ambiente”(イタリア語で社会的、 文化的環境、周囲の意味; 伊和中辞典・第 2 版, 1999, 小学館）、あるいは、“environment”として、園舎、保育室、 設備、家具、道具、教具について説明している (1) E8083, I59-61; (4) E46-47, I50-52; (4) E62-63, I68-69)。さらに、 モンテッソーリは “Ora dell'ambiente fa parte anche l'adulto” （しかし、環境の中には大人（教師）も入る）と述べてい
る（Montessori, 1999a, p. 147, 著作(2)のイタリア語版)。し たがって、モンテッソーリ教育における環境は、「人とモ ノ」すなわち、「人的環境」と「物理的環境」で構成される。

さらに、注目されるのは、モンテッソーリは活動の主 体である子どもに発達の自由を与える環境とは、「人的環 境」である教師は消極的であるべきとし、それに代わり「物 理的環境」が子どもの活動を喚起・援助することが適切 であるとしたことである（8 J51,E27）。

\section{（3）現実的・具体的な実践を重視する}

モンテッソーリが重視したのは現実的で具体的な実践 であった。これは、抽象的で普遍的な知識も、真の創造も、 生活習慣の自律も、実践と身体的な活動によって現実を 具体的に把握することを通してでしか獲得、あるいは実 現できないと考えたからである。つまり、いわゆる「日 常的認知」（稲垣・波多野，1989）を重視したのである。

このような考えに立ち、モンテッソーリ教育における 3 つの主要な活動、(1)教具の練習、(2)日常生活の練習、(3) 社会性の獲得が提案された。

(1) 教具の練習

モンテッソーリ教育では感覚教具と、言葉や数など学 習に関連する教具が使用された。教具はモンテッソーリ によって考案され、厳密に規格化された。中でも特徵的 な感覚教具は、色、音、形状、寸法などの物質の性質と いう抽象概念を具体的な形にしたものであり (4) J121122, E100-101）、この教具の使用により身体を通して抽象 概念を具体的に理解するとされた。

(2) 日常生活の練習

日常生活の練習とは、生活で行われる家事（掃除、食 卓の準備、食器洗いなど）、身支度（手を洗う、髪をとかす、 靴を磨くなど）、社会習慣（あいさつや教会での礼拝、人 に道を譲るなど）を身につける練習である。これらは家 事を含めた生活習慣の自立、すなわち、「セルフケア」（self care）の獲得を目指寸活動であると言える。このような日 常生活の練習は、子どもの属する社会の文化に応じて行 うべきだとされた（3) J165, E168-169, I167-168; (4) J100, E82, I91)。

この練習では、教師がそれぞれの行為のやり方をすべ て丁寧に教えるが、実践は子どもに任されることに特徵 があった。これは、習ったことの中から実際の日常生活 の様々な場面において、適切なふるまいや行為とは何か、 子ども自らが考えて行動することこそが重要であり、そ れによって真に熟達するとされたからである（4) J113115, E92-94, I103-105; (4) J102, E83)。

さらに、身体の動作の熟達も日常生活の実践によって 目指された。モンテッソーリは、日常生活の練習には、 身体のバランスや動作を洗練させる練習が豊富に含まれ ているとした。例えばイスを並べる、カーペットを巻く、 こぼさないように食事を運ぶなど、日常生活の練習に含 まれる動作を実際の生活の中で繰り返し練習することに よって、身体のバランスや動作が本当の意味で熟達する とした（4) J100,E81-82, I90-91）。 
日常生活の練習には、階層を問わず、すべての子ども が取り組んだ。モンテッソーリは、彼女が最初に教育を 始めたスラム街の下層の子どもだけではなく、裕福な家 庭の子どもも過剰に保護されて養育されることが多く、 生活習慣の自立が難しい状況にあると指摘している（2) J96-97, E79)。このようなことから、階層にかかわらず日 常生活の練習は続けられたのだと考えられる。さらに、 この練習は性別を問わずに実施されたことも、大きな特 徽である。早田（2003）によれば、当時のイタリアの小 学校では、「女性の仕事」という教科が設置されており、 女児だけに縫い物と編み物を中心とした授業が行われて いたといい、男女を問わず家事に取り組んだモンテッソー リ教育は、革新的であったといえよう。

モンテッソーリは性別を問わずに、すべての子どもが 尊㛜をもって生活するには、まず家事を含めた生活習慣 の自立、つまり「セルフケア」を獲得することが不可欠 だと考えたのではないだろうか。早田 (2003) は、モンテッ ソーリが男女ともに日常生活の練習に取り組ませたのは、 女性解放思想の影響であると指摘し、注目すべきことは 対象を女子だけに限定するのではなく、男女ともに人間 の個々の可能性を模索しようとした点であると指摘して いる。確かに、モンテッソーリは女性解放運動に参加し ており（Foschi, 2008）、第一波フェミニズムの思想に影響 を受けていたと考えられる。

(3) 社会性の獲得

社会性の獲得は、異年齢クラスでの日常生活の実践に おいてなされるとした。異年齢クラスは $3 \sim 6$ 歳児で構 成され、 1 クラス 40 名が理想的な人数であるとされた（10) J105-106, E64-65)。モンテッソーリは社会生活の魅力とは 様々な人に出会うことであり、年齢によってクラスを分 けるのは不自然な隔離であり、社会性の発達が阻害され るとした（3）J219-220, E226）。さらに、社会生活とはそ れぞれが自分の仕事をしながらも、互いに社会の一員と して調和することであるとした。すなわち、子どもたち は社会生活と同様に異年齢の仲間の中で、個別の活動を しながらも、互いを尊重し、調和し、助け合いながら活 動し、問題が起きたときには子ども同土で解決すること で、真の意味での社会性を身につけるとされたのである (10) J40, E24)。

\section{3 モンテッソーリ教育における環境}

ここまでの分析で、子どもは自らの発達の法則・計画 に忠実に従い環境と相互交涉し、発達するという「子ど も観・発達観」に基づき、子どもの自律的活動を尊重す るように「教育の原則」が明確にされ、適切な環境一「人 的環境」と「物理的環境」一を整えることが重要である とされたことを明らかにした。また、「人的環境」にかわ り、「物理的環境」が子どもの自律的活動を喚起・援助す るとされたことも注目された。本節では、モンテッソー リ教育における環境の性質と具体的な特徵について、図 1 に沿って分析の結果を述べる。

\subsection{1 人的環境 : 教師}

\section{（1）子じもを信頼し敬意を払う}

まず教師がなすべきことは、自分自身の準備をするこ とであるとされた。教師は子どもに対する先入観を捨て、 謙遜の心を持たなくてはならない（(2)J179-180, E153)。 子どもは自らの発達の法則・計画に従い、環境と相互交 渉することによって発達し、さらに「正常化」し本来の 姿を表すようになるのだと理解し、子じもを信じ（3) J273, E276)、敬意を払うべきだとされた。モンテッソー リは、教師が子どもを理解し、敬意を払うことが、モンテッ ソーリ教育における特徵の一つだとした（2) J130, E111; (8) J39, E20-21)。

\section{（2）消極的にふるまう}

従来、教師は権威をもち、子どもの活動を抑制する、 教室で自由に活動する唯一能動的な存在であった（4) J65, E51)。しかし、モンテッソーリはこのような教師の権威 や能動性は、子どもの自律的活動を妨げる大きな障害に なりうるとした。子どもは教師の言葉によってではなく、 環境との交渉によって自ら発達するのであり（3) J6-7, E8; (5) J56, E39)、教師には子どもの自律的活動を尊重するこ とを求めた（3） J277, E280）。

モンテッソーリはこのような教師のあり方を「消極的 態度」（passive attitude）と表現し（2) J130, E111）、さらに 教師を「指導者」(directress) という名称に変更した。こ れは、モンテッソーリ教育の教師は、従来の教師のよう に教えるのではなく、子どもを発達の法則・計画に基づ く自律的活動に導き、その活動を尊重するからであった (4) J191, E162, I179; (7) E295)。

\section{（3）子どもへの教示・介入は限定的にする}

「消極的」な教師は、子どもへの教示や介入も非常に制 限された。教示はそれぞれの子どもの活動を尊重するた め、個別に行う。子どもの注意がそれないように、客観 的に、簡潔に、正確にすべきとされた。さらに、子ども の意欲を奪わないように、子どもが理解できなかったり、 間違えた場合、レッスンを繰り返したり、子どもに間違 えたことを伝えてはならないなどの配慮が求められた（4) J127-128, E106-107; (7) J145-146, E73-74)。

子どもへの介入も制限された。モンテッソーリは、子 どもを手伝う、ほめる、さらに、眺めることでさえも、 子どもの自律的活動を妨げることになるとした。したがっ て、教師は子どもが集中して活動し始めたら、気づかれ ないように、まるでその子が存在しないつもりで振る舞 いながら、子どもの観察に徹しなければならないとされ た (3) J277, E279-280)。

さらに、たとえ子どもの間で問題が起こっても、子ど もが助けを求めない限り、教師は介入す心゙きでないとさ れた（3）J277, E280)。また、子どもが活動の合間に休ん でいる時には、作業に戻るように呼び戻したりせず、子 どもを尊重すべきであるとした（10) J31，E19）。

ただし、モンテッソーリが教師が介入すべきだとした 
場面が、2つあった。1つは子どもが助けを求めたり、ほ めてもらいたいというような気配を示している場合であ り、教師はそれに惜しみなく応じてやるべきであるとし た（11) J148, E69; (8) J63, E33)。もう1つは、教具を正し く使用していなかったり、集中して活動するのではなく、 他の子どもの邪魔をしている時なども、教師は積極的に 介入すべきだとされた（8) J125-126, E65-66）。

\section{（4）物理的環境を整える}

前述のようにモンテッソーリは、「消極的」な教師に代 わり、物理的環境が子どもの自律的活動を喚起・援助す るとした。この物理的環境を用意し、整えるのが教師の 重要な仕事であった。教師は、子どもの活動に必要なも のをすべて用意し、子どもが常に使えるように手入れし、 秩序正しく置き、教室に入ってきた子どもがすぐに魅了 され、自律的な活動が促されるようにしなければならな いとされた（3) J274-275, E 277-278; (10) J23, E14)。

\section{（5）魅力的である}

子どもの信頼と尊敬を得るために、教師は魅力的でな ければならない。教師は明るい感じを与え、清潔で物静 かで威厳があり、動作もできるだけ美しく優雅であるべ きだとされた（3) J274, E277; (10)J23, E14)。

\subsection{2 物理的環境: 物理的環境に共通の 8 つの性質}

モンテッソーリは、「消極的」な教師に代わり、物理的 環境が子どもの生まれながらに持つ発達の法則・計画に 基づく自律的活動を喚起・援助するとした。まず、この ような物理的環境に共通の 8 つの性質をまとめ、次節で、 モンテッソーリが著作の中に記述した物理的環境の具体 的な特徴を明らかにする。

\section{（1）子じもサイズである}

子どもの自律的活動に適切な物理的環境の設定には、 子どもの a. 体格、 b. 体力、 c. 理解力を考慮する必要があ るとされた（3) J165, E169; (9) J21, D17; (12) J120, E95)。モ ンテッソーリはこの 3 点に配慮してこそ、子どもに適切 な環境になると考えたのだと思われる。なお、モンテッ ソーリは「子どもサイズ」と言う語を使用していないが、 子どもの a. 体格を考慮するだけでは不十分であり、b. 体 力、c. 理解力をも考慮するよう強調していることから（9) J66-67, D44-45)、本論文ではこれら 3 点を考慮した物理的 環境を「子どもサイズ」と呼ぶことにした。

子どもの a. 体格に配慮するとは、たとえば、家具は子 どもの体格に適切な寸法にし、空は子どもが外を眺めら れる高さに設置する (2) J131，E111）。さらにb. 体力を考 慮すると、家具は子どもが容易に持ち運べるように軽量 であるべきだとされた（8）J80-81，E42）。c. 理解力とは、 子どもは発達の過程にあり、まだ十分な理解力が身につ いていないため、子どもが理解しやすいように、例えば 単純化したり、簡単なものを用意する例が挙げられた（2) J92, E74, I99-100; (9) J66, D44-45)。

\section{（2）フィードバックを与える}

学びでは誤りに気づき、それを訂正していくことが必 要であるが、従来の教育法では、子どもの誤りに気づく 役割を担うのは教師だけであった。しかし、常に教師の 援助を必要とするのであれば、子どもの自律的活動を尊 重するモンテッソーリの考えとは相容れない。そこで、 モンテッソーリは、子ども自身も誤りに気づく手段を持 つべきであると考え（3）J241-242, E247-248）、物理的環 境からのフィードバックによって、子ども自身が誤りに 気づき、自律的に学ぶことができるように配慮した（8) J53, E28; (9) J23)。

たとえば、子どもが容易に動かせる軽量なイスは、子 どもの動作が不完全であれば、イスを動かす時にガタガ タと音がしたり、倒れたりする。それによって子どもは 自分の動作がまだ不完全であることに気づき、動作に気 をつけるようになる。イスを倒さず、音が立たなくなると、 子どもは自分の動作が完全になったことを知る（1） J69， E83-84)。このように、フィードバックは誤りだけでは なく、正しくできたことも子どもに知らせるので、自己 学習が可能になる。モンテッソーリ教育では、教具、道 具、家具、設備や建物に至るまで、すべての物理的環境 が子どもの活動にフィードバックするよう配慮される (4) J124, E103)。

ここで留意しなければならないのは、モンテッソーリ のいう物理的環境からのフィードバックによって子ども に誤りを気づかせるとは、子どもが痛い目にあい、それ を避けるようになるという考えとは異なるということで ある（7）E204-205）。通常の環境では、環境からのフィー ドバックがないため、子どもは呮った動作をしているこ とに気づきにくく、ケガなどの、言わば痛い目にあい、 そこで初めて詋った動作であったことに気づく。一方、 モンテッソーリ教育の物理的環境では、子ども自身に容 易に誤りを気づかせ、見落とすことがなく、その誤りを 自ら訂正し、学ぶように物理的環境がフィードバックす ることが特徴である。

発達心理学者の波多野と稲垣（1973）は、子どもの反 応に応じる環境からの応答（フィードバック）は、子ど もの好奇心を刺激し活動を持続させる、子どもの知的教 育に好ましい条件であると述べ、その良い例として自己 教授的なモンテッソーリの教具を挙げている。

\section{（3）内発的な活動を考慮する}

子どもの発達のためには、発達の法則・計画に従い環 境との相互交渉ができるように、子どもの自律的活動を 尊重することが必要である。しかし、活動に必要な外的 な手段が与えられなければ、子どもは活動できず、発達 することもできないとされた（8）J51-52, E27; (9) J70)。

そのため、物理的環境は、発達の法則・計画に基づく 子どもの内発的な活動を考慮して設定するべきだとされ た（4) J342-343, E305; (12) J124, E98)。 
（4）活動を動機づける

物理的環境は、子どもに活動したいと思わせるもので なければならないとされた（3）J94, E92; (7) E60)。子ども の活動を動機づけるために、「美しさ」と「手を使って活 動できること」の 2 点が重視された。すなわち、色や形 が美しく、魅力的な物理的環境は、子どもの注意を引き、 活動を喚起する（８Ｊ53-54, E28）。さらに、3〜6歳児は 身体機能が発達し、手による活動が活発になるため、手 に取って使用できる教具や道具は、子どもの活動を動機 づけるとされた（4)J125-126, E104, I115）。

\section{（5）興味を継続させる}

子どもは発達に必要な活動を、それを習得するまで何 度も繰り返す。そのため、物理的環境は、繰り返し活動 できるように、子どもの興味を継続させるものでなけれ ばならない。例えば、教具は表面を観察するだけではなく、 手に取って活動できるので、子どもの興味を長く引き付 け、継続した活動を可能にするとした（4) J125-126, E104, I115; (7) E148-149; (7) E178)。

\section{（6）集中した活動を促す}

子どもは発達のために、集中して活動を行うことが必 要だとされた。モンテッソーリは子どもを観察し、子ど もが集中して使用するものだけを物理的環境として採用 した。子どもの集中を促す環境のあり方についても研究 し、園舎や保育室も集中して活動しやすいように設定さ れた（8) J61-62, E32)。

\section{（7）本物の性質を備える}

モンテッソーリは実践を重視した。特に日常生活の練 習では、実際の日常生活の中で実践しなければ、真の熟 練には達しないとしている（4) J113, E92）。そのため、物 理的環境は「子どもサイズ」であるものの、活動を実践 することができる本物でなければならないとした（6) J11， E10; (6) J15, E15)。さらに、子どもは大人の世界の一員に なることを望んでいるのであり、実際の日常生活で使用 できる本物でなければ、子どもは興味を示さないとされ た（3) J165-166, E169-170, I167-168; (11) J107-110, E50-51)。

\section{（8）魅力的で豊かである}

物理的環境は魅力的で豊かでなければならないとされ た。その例として、花や絵画などの装飾や、テーブルク ロスの使用について述べている。また、家具も魅力的な ものであるべきだとし、例えば子どもが日常的に使用す る木製のイスは魅力的、あるいは洗練されたものである ベきだとし、籐のイス、肘掛けイス、ソファを置くのも 良いとするなど、家具にも多様性をもたせる必要がある ともしている (1) J67, E81, I60; (4) J60-61, E46-47)。

Standing（1957/1975/1998）によれば、“The best for the smallest”、「1番よいものは1番小さい人に」（Standing, 1998, p. 268; スタンディング, 1975, p. 388) がモンテッソー リのモットーであったといい、物理的環境はできるだけ
美しくする心゙きであると考えていたという。しかし、モ ンテッソーリは美的な配慮と子どもの活動に矛盾が生じ た場合には、活動を優先す心゙きだと強調したと言う。た とえば、美的に優れたテーブルであっても、子どもが動 かせない重いものであるならば、「子どもサイズ」である テーブル、つまり、よりシンプルで軽量のテーブルに代 えるべきだとされた。

\subsection{3 物理的環境：「子どもの家」の環境}

以下では、モンテッソーリが記述した物理的環境の具 体的な特徴を詳細に明らかにする。

モンテッソーリは “Quando parliamo di 《ambiente》 comprendiamo tutto l'insieme delle cose che il bambino può liberamente scegliere in esso e usare tanto quanto desidera, cioè corrispondentemente alle sue tendenze e ai suoi bisogni di attività.”（モンテッソーリ教育における「環境」とは、子 どもたちに用いられるもの全体を言う。これは、子ども たちが自由に選択し、喜んで使うもの、つまり、子じも たちの必要や傾向に合っているものである。）（Montessori, 1999c, p. 69, 著作(4)のイタリア語版) と述べており、モ ンテッソーリは子どもが使用するものすべてを物理的 環境と考えていたと言える。そして環境（イタリア語： ambiente, 英語 : environment) として、建築（園舎）、設 備、家具、道具について言及しているのである（1) J6670, E80-85, I59-63; (4) J60-61, E46-47, I50-52; (6) J11-15, E915)。

そこで、本節では、考慮すべき物理的環境でありながら、 これまでほとんど体系的にまとめられなかった建築（園 舎)、設備、家具、道具について図 1 に沿って詳しく述べ ていく。

モンテッソーリは、物理的環境は、前述の (1) 〜 (8) の物理的環境に共通の 8 つの性質を実現するのが望まし いとしたといえる。そして、この8つの性質を物理的環 境としてどの様に実現するかは、以下のように、各教育 施設の状況や文化に応じて設定することを奨励したと考 えられる。

前述のように、モンテッソーリは教具を厳密に規格化 した。これとは対照的に、モンテッソーリは自身の教育 施設である「子どもの家」には決まった形はないとし、 財政状況や保育時間、空間的な状況に応じて変わりうる とした (4) J100-101, E81-82; (6) J11, E9)。さらに、モンテッ ソーリは最初の「子どもの家」について、子どもが教師 から教えられなくても、環境から吸収することができる ように、環境には文化が散りばめられていると述べてい る (3) J6, E7, I5)。この文化とは、子どもが属する社会の 文化を指す。すなわち、「子どもの家」の物理的環境は、 それが属する社会の文化によって、どのように具体化さ れるか変わり得るのである。

モンテッソーリ教育に関する最初の著作（著作(1)のイ タリア語版）であるIl metodo della pedagogia scientifica applicato all'educazione infantile nelle case dei bambini (Montessori, 1909; 以下、Il metodo と表記) について、モ 
ンテッソーリは 1907 年に教育を開始してから 2 年間の 実践の記録であると述べている（1Ｉ27）。この Il metodo では、「子どもの家」における物理的環境を具体的に述心 た後、最後に “Ecco l'ambiente.” (Montessori, 1909, p. 61)、 「これが環境である」と述心゙るにとどまっている。一方、 Il metodo の英語翻訳本である 1912 年に出版された The Montessori Method（著作11の英語版）では、「子どもの家」 における具体的な物理的環境を述べ、最後に“This, then, is the environment which I have selected for the children we wish to educate.” (Montessori, 1912,p. 83)、「これが、われわれが教 育しようとしている子どものために、私が選んだ環境であ る。」（モンテッソーリ，1974，p. 68）との一文が加えられ ている。1912 年に英語翻訳版として The Montessori Method が出版されるにあたっては、モンテッソーリ自身が大幅に 加筆修正したことが明らかになっている ${ }^{(1)}$ 。つまり、原 書であるIl metodo に見られないこの一文は、英語翻訳版 が出版されるにあたって、モンテッソーリが加えた一文で あると考えられる。

この一文を加えることで、モンテッソーリは、「子ども の家」の物理的環境亡して具体的に記述したこの環境は、 イタリアの子どものために、イタリア文化を反映して、 自身が選んだものであると強調したかったのではないだ ろうか。したがって、モンテッソーリが著作で記述した 具体的な物理的環境は、イタリアの子どものために、イ タリア文化を反映して設定した一例であると解釈するの が正しいと考えられる。

寸なわち、物理的環境が備えると望ましいとされたの は、前述の物理的環境の 8 つの性質であり、この性質を どのように実現するかは、各教育施設が属する文化や状 況に応じて行うことを任されているのである。したがっ て、以下にまとめた物理的環境の具体的な特徴は、必ず 守らなくてはならない特徵ではなく、8つの性質を実現し た一例であると解釈すべきであろう。

では、モンテッソーリが一例として挙げた物理的環境 の具体的な特徵から、何が読み取れるのだろうか。前述 のように、モンテッソーリは、子どもが自由に選択し、 使用するもの全体を考慮するべき物理的環境としており (4) J79-80, E62-63，I68-69）、彼女が著作で記述した物理的 環境の具体的特徴も、建築（園舎）から道具に至るまで 多岐にわたった。特に、道具では子じもが使用する石け ん、掃除道具である雑巾やほうき、食器ではコップや血、 さらにスプーンやフォークなどの細かなものの記述も見 られる。物理的環境は子どもが使用するもの全てであり、 その一つ一つ、たとえ小さな道具であっても、すべての ものが子どもの自律的活動を喚起・援助するように整え るべきだとするモンテッソーリの姿勢が、ここに、表れ ていると思われる。

つまり、モンテッソーリが強調したかったのは、具体 的な物理的環境は文化や財政状況、保育時間などに応じ て整えれば良いものの、建築から小さな道具に至るまで、 子どもが使用するものすべてを、子どもの発達を援助す るべく、物理的環境に共通の性質を実現するように整え
なければならないということだといえよう。物理的環境 に共通の性質とは、前述の（1）子どもサイズである、(2) フィードバックを与える、（3）内発的な活動を考慮する、 （4）活動を動機づける、（5）興味を継続させる、（6）集 中した活動を促す、（7）本物の性質を備える、（8）魅力 的で豊かである、の 8 つである。

以下、この 8 つ性質を実現した一例として、モンテッ ソーリが著作に記述した具体的な物理的環境について詳 しく述べていく。

\section{(1) 教具}

教具はモンテッソーリが考案し、綮密に規格化した。 生産も許可した製造者にのみ行わせるなど、厳しく管理 した（7）E293）。教具は感覚教具と言語、数、音楽などの 教科学習に関する教具などがあり、相互に関連し体系化 された（7) E11-12）。

(2) 建築

(1) 園舎

- 園舎の構成「子どもの家」は実際の家庭と同じく、数 種の部屋と庭から構成されるとした。子どもが自由に使 い、知的な作業をする部屋は主室と呼ばれ、これが現在 の保育室にあたると考えられる。この主室に加え、事情 が許せば浴室、食事室、居間または休䄭室、工作室、体 育室、洗面所などの小さい部屋を設けるとよいとした（6) $\mathrm{J} 11, \mathrm{E} 9-10)$ 。

園舎の構成については、モンテッソーリが「オープン・ ドア」の有効性に言及していることが興味深い（10) J106108, E65-66)。「オープン・ドア」とは、文字通りドアを 開け放しておくほか、教室の仕切りをガラスにする方法 があげられ、開かれた教室にすることを意味する。この ような工夫により園舎内での子どもの回遊性を高め、子 どもに活動の内容と、活動の場所の選択の自由を与える という「教育の原則」を実現することを意図した。さらに、 子どもの背丈程度の低い壁によって教室を仕切る方法も 挙げられている。これにより教師が園舎内の寸べての教 室を見渡すことが可能になり、子どもの活動を制限する 必要がなくなり、子どもの自由な活動をさらに援助する ことができると考えられる。

・庭 当時、幼児施設に庭を設けることは珍しいことで はなかった。モンテッソーリが庭に関して刷新した点は、 保育室から直接、庭に出ることができるようにしたこと である。子どもは一日中、好きな時に庭に出入りしてよ いとされた（1）J67,E80-81, I59-60）。庭は、子どもが興味 を持って認識できる適切な広さでなければならないとさ れた（4) J92-93, E74-75)。さらに、庭には屋根を設ける ことが望ましいとし、屋根があれば、植物の世話や畑仕 事をするだけではなく、遊びや午睡、テーブルを運べば 活動や食事など、一日中のほとんどを屋外で過ごせるとし た（6) J11, E9)。

(2) 子どもが使用する部屋

特に言及されている部屋は、保育室と居間についてで 
あった。モンテッソーリは、園舎、部屋、ドア、空も「子 どもサイズ」でなければならないとした（9) J21，D17; (12) J120, E95)。これは、子どものサイズに合わせて、部屋 を小さくしたり、ドアや空を小さくするということでは なく、子どもが大人の手を借りなくても使用できるよう に配慮することを意味している。例えばモンテッソーリ は、子どもが外を眺められる高さの空の設置や (2) J131， E111)、子どもの手が届かない高さにドアノブがある場合 には、ドアをカーテンで代用することを提案している（9) J66, D45)。

・保育室（主室）モンテッソーリ教育では活動の主体は 子どもであり、教師は従来の教育のように子どもを教え るのではなく、子どもの自律的活動を尊重する。そのた め、保育室には教壇や教師用の机は置かれない（2) J131, E111; (9) J65, D44)。黒板も保育室の正面の高い位置にで はなく、四方の壁の子どもの手が届く低い位置に設置さ れた（4) J61，E47）。また、子どもがカーペットを広げて 床の上で活動できるように、従来の保育室に比べて床の スペースを広くとるべきとされた（6) J12,E12）。

加えて、保育室は豊かで魅力的な空間であるべきとさ れた。教室には観賞用の植物や花が常に置かれ（6) J12, E12)、芸術的な絵画も飾られた。風景画や花や果物など を描いた静物画、家族や子どもを描いた人物画、聖書や 歴史上の出来事を描いた絵画などが飾られ、時々掛け替 えるとされた（4)J61，E47）。これらは子どもの身長に合 わせて低い位置にかけられた（8) J81, E42）。

・居間 居間は、子どもがおしやべりやゲーム、音楽を 楽しむ部屋であり、前述のように余裕があれば設けると よいとされた部屋のひとつである。モンテッソーリは、 居間は特に趣味豊かで、魅力的な空間であるべきだとし た。様々な大きさのテーブルと、ひじ掛けイス、ソファ など多様なイスが置かれるとよいとされた。棚には、小 さな彫像や写真、花などを飾り、子どもが楽しむ写真集 やゲーム、子どもサイズの楽器なども置くとよいとした (6) J12-14, E12-13)。

\section{(3) 設備}

(1) 設備

・洗面台 モンテッソーリがたびたび言及している設備 は洗面台である。洗面台は 3 歳の子どもでも楽に使える 高さに設置された（7）E278）。洗面台の脇には石けんや 爪ブラシ、タオルなどを置くスペースがあり、白く塗り、 掃除しやすくするのがよいとされた(4)J61, E47)。さらに、 場所に余裕があれば戸棚を設け、子どもが各自の石けん や爪ブラシ、歯ブラシなどを置けるようにするとよいと された（1) J67, E81, I60）。

なお、モンテッソーリは日常生活の練習の例として、 食器洗いなど台所に関連する練習を挙げているが (4) J79, E62-63, I68; (6) J14, E14)、著作の中で洗面台以外の設備に ついて具体的に記述された箇所は見られなかった。当時、 正しい衛生の知識の習得は重要であり、モンテッソーリ は洗面台は文化を超えてぜひ設置すべき設備であると考
え、繰り返し詳述したと考えられる。一方、台所は文化 を強く反映するものであるため、記述が控えられたので はないだろうか。

(2) 家具

モンテッソーリが著作の中で言及した家具は、机、イス、 教具棚、私物棚、洋服ダンスの5 点である。前述の物理 的環境に共通の 8 つ性質に加えて、モンテッソーリが 家具に共通の特徴としたのは、明るく薄い色または二ス を塗り、水洗いができるようにすることである（6) J11， E10; (8) J53, E28; (8) J82, E43)。家具は明るく薄い色で塗ら れているために污れが目立ち、それがフィードバックと なり、子どもは污れに気づき洗うこと（掃除）が促される。 家具を洗うのはイタリアなどの欧米の掃除の習慣であり、 国や地域の文化を反映する日常生活の練習と、それに適 した物理的環境の設定の例のひとつであるといえる。

・机とイス モンテッソーリが実施した机とイスに関す る最も大きな変革は、机とイスを連結することや、床へ の固定をやめ、さらに、子どもが持ち運べるように机と イスを軽量化したことである。Dudek（2000）もこれらを、 モンテッソーリ教育における物理的環境の特徴だと指摘 している。

20 世紀初頭当時、学校では「国民的ベンチ」(イタリア 語 : banco nazionale, 英語 : national desk) と呼ばれる、特 許を取得した「机のついたイス」が広く普及していた（1) J19-20, E16-17, I16-17)。この「国民的ベンチ」が考案され る以前は、子どもは座面の奥行きが浅く、細長いイスに 詰めて座らされていた。その後、当時の最新の科学の成 果を元に「国民的ベンチ」が考案されたのである。当時、 子どもは乱雑で無秩序であると考えられ、できる限り動 きを抑制して教育すべきだとされていた。そのため、子 どもの活動を抑制することに、もつぱら当時の最新の科 学的知見が活用され、「国民的ベンチ」が製作されたので ある(1) J68-69, E83, I61-62)。

「国民的ベンチ」は当時の最新の人類学の研究成果を もとに、子どもの年齢や足の長さなどを考慮してイスの 高さや、机とイスの距離が決められた。このため、机と イスは連結され、その距離は固定されていた。子どもが 立ち上がることは想定されておらず、まっすぐな姿勢で 座るだけのスペースしかなく、隣に座る友だちからも離 すように考案された。しかも、このベンチは子どもが動 かせないように重く、床に固定されることもあった（7) E364)。

この「国民的ベンチ」は机、イス、足を置く足台から 構成されていた。モンテッソーリはIl metodo（著作(1)の イタリア語版）において、この「国民的ベンチ」の机を “leggio”（書見台）という語で表しており（1）I16）、主に 聴講を目的としていたと考えられる。モンテッソーリに よれば、このような「国民的ベンチ」は学校だけではなく、 幼稚園でも使用されていたという（4) J23, E10, I11）。 モンテッソーリは、この「国民的ベンチ」に子どもが 不動の状態で座らされることは、身体や精神の抑圧であ り、学校で子どもが奴隷のように扱われていることの顕 
著な例であると批判した（7) E276-277）。Burke ら（Burke \& Grosvenor, 2008） も、このモンテッソーリによる批判を、 教育施設の物理的環境の变革における事柄の 1 つとして 記述している。

モンテッソーリはこのように批判するとともに、この 重く、固定された机とイスを廃止した（1) J67, E81，I60）。 これらは、「国民的ベンチ」と呼ばれるほど広く普及して いたのであり、これを廃止することは、非常に大きな変 革であったといえる。

モンテッソーリは、イスを家庭などで馴染みのある、 軽量な 1 人掛けのものにした（7）E278）。イスは木製で、 魅力的なデザインであり、単に大人用のイスを小さくし たものではなく、子どもの身体に調和したものであった (1) J67, E81, I60; (4) J60, E46)。

机は、どこにでも見られるような、シンプルなテーブ ルに替えられた（7）E278）。テーブルは 1 人用から 2 〜 3 人用まで様々な大きさで、長方形や正方形、丸形など様々 なものが用意された（6) J11，E10）。テーブルは子どもの 体格に合わせた高さで、丈夫な作りであるものの軽量で あり、 2 〜 人用の大きなものでも 4 歳児が 2 人で運心゙る ほどの軽さであった（1) J67, E81, I60)。

1909 年に刊行されたモンテッソーリによるモンテッ ソーリ教育についての初の著作であるIl metodo には、「子 どもの家」で使用されたテーブルの図面が掲載されてい る (Montessori, 1909, p. 49 の後の折り込みに掲載の図)。 Schneider（Müller \& Schneider, 2002）によれば、これは 1907 年に開設した最初の「子じもの家」のために、モンテッ ソーリ自身がデザインしたテーブルだという。テーブル は幅 $129 \mathrm{~cm}$ 、奥行き $49 \mathrm{~cm}$ 、高さ $54.5 \mathrm{~cm}$ であり、2〜3 人用のテーブルであったと推測される。1927 年にドイツ においてモンテッソーリ教育のためにデザインされた机 の高さは $48 \mathrm{~cm}$ (Müller \& Schneider, 2002,p. 61) であった。 現在のわが国の 4、5 歳児が使用寸る机の高さは $45 \sim 48$ $\mathrm{cm}$ 程度とされ（小川, 1985; 日本建築学会, 2005)、これ らと比較するとIl metodo に掲載されたテーブルの高さは、 子どもにとっては多少高すぎるとも思われる。しかし、 次の Deweyの例に見るように、当時は子どもが自律的に 活動するための家具はほとんど製作されていなかったの であり、モンテッソーリも試行錯誤を重礼ていたのだと 推測される。

19 世紀末に、Deweyは「国民的ベンチ」のような 子どもの聴講用の机とイスはあっても、子どもが作業 するための机とイスはなかったと述べている（Dewey， 1900/1902/1915/1957/1990)。モンテッソーリはこの Dewey の記述を引用し、確かに子ども用のものは何もないと同 意し（3）J166, E169-170）、「子どもにふさわしい家が存在 しないのなら、それを建てましょう。子どもにふさわし い品物が作られていないのなら、それらを作らせましょ う。」（モンテッソーリ，1993, p.10, 文献12)の日本語版） と 発言したとされる。このように、モンテッソーリは、子 どものための家具を作る先駆者であり、「子どもサイズ」 について、検討を重ねていたと考えられる。
モンテッソーリは、この軽量で持ち運ぶことのできる 机とイスはモンテッソーリ教育の自由を象徴している（an external sign of liberty）と述べている（1) E84）。また、軽 量で動かすことができる机とイスは、前述のように子ど もにフィードバックを与える教育の手段でもあった（1) J69, E83-84, I62; (7) E364-365)。

・教具棚・私物棚・洋服ダンス モンテッソーリは教具 棚と私物棚を保育室に欠かせない家具とし（6) J12, E1011)、さらに洋服ダンスにも言及した。

教具棚は、子どもが共同で使う教具が置かれる棚で、「子 どもサイズ」であり、低く横長で戸がつき、軽量で単純 な（simple）棚であった（1) J67, E81-82; (6) J12, E10-11）。 戸は簡単に開けられ、鍵がついているものもあったが、 鍵も子どもの手の届くところに置かれ、子どもが教具の 出し入れを行った。戸のかわりにカーテンがついている 棚もあった。教具棚の高さは大変低く、子どもでも教具 棚の上に植木鉢や小さな水槽、おもちやなどを置くこと ができるほどであった。

私物棚は、小さな引き出しが $2 、 3$ 列並んだタンスで、 子どもはそれぞれ自分の引き出しを持っており、その中 に私物を入れておく。引き出しには明るい色のつまみか、 引き出しの色と対照的な色のつまみがついており、子ど もの名前が書かれた紙を、それぞれの引き出しに貼ると された（6) J12，E11）。モンテッソーリは子どもに活動場 所の選択の自由を与えたが、一方で大人と同様に子じも にも自分の場所と呼べる、いつも自分のものを置くこと ができる決まった場所が必要だと考え、私物棚が置かれ た（10) J109-110,E67-68)。

洋服ダンスも低いものが設置された。中はいくつかに 区切られていて、扉にはそれぞれ鍵がついており、子ど もは各自のスペースを与えられた（7）E278）。

(3) 道具

日常生活の練習は子どもの属する文化に応じて行われ る。モンテッソーリはその文化において行われているこ とであれば、子どもは日常生活の練習として何でも行う ため、「子どもの家」の道具には制限がないとした（6) J14, E14)。そのため、道具は、前述の物理的環境の 8 つ の性質を考慮しながら、文化に応じて用意すればよいと いうことだと考えられる (3) J165, E168-169, I167-168; (4) J100-101, E82, I91; 8) J81, E42-43)。これは厳密に規格化さ れた教具とは対照的である。道具を代表して具体的に言 及されたのは、掃除道具と食堂・食器に関連するもので あった。

・掃除道具 注目されるのは、子どもの活動の動機づけ となるように、掃除道具も「子どもサイズ」の美しいも のであるべきとされたことであった。子どもの手のひら に入るサイズの色とりどりのぞうきんや、きれいな柄の ほうき、面白い形をした石けんの例が挙げられた（8) J53-54, E28; (8) J81-82, E42-43)。

・食堂・食器 食堂にはテーブルだけではなく、食器棚 などの家具を置くとされた。食器棚はすべての子どもの 手が届くほど低く、子どもが食器やスプーン、ナイフ、 
フォーク、テーブルクロス、ナプキンなどを出し入れす ることができた（6) J14, E13）。食器は必ず陶器またはガ ラス製であり、金属のナイフも用意されたことが注目さ れる。これはモンテッソーリが本物の道具での実践を重 視したためだと思われる。さらに、陶器やガラスの食器 は扱いを誤ると割れ、それが子どもへのフィードバック になるとされた（8) J53,E28）。

\section{4. 討 論}

\section{1 分析のまとめ}

本研究の目的は、モンテッソーリ自身の 12 点の著作 の記述内容を分析して、（1）モンテッソーリ教育の教育 理念と人的環境・物理的環境の全体像を明らかにし、（2） 物理的環境の性質と教具以外の物理的環境の具体的な特 徵を明確にし、（3）なぜ、モンテッソーリ教育では物理 的環境が重視され、どのようにモンテッソーリの教育理 念が反映されているのかを分析することであった。分析 の結果は、以下のようにまとめられる。

\section{(1) モンテッソーリ教育の全体像}

12 点の著作の記述から、モンテッソーリ教育の全体像 は図 1 に示したように整理できた。モンテッソーリは明 確な「子ども観・発達観」を持っていた。子どもは発達 する可能性を生まれながらに持ち、それぞれの子どもの 持つ発達の法則・計画に基づいて活発に自律的活動をし、 環境と相互交涉することによって、その可能性を実現し、 発達するとしたのである。

このような「子ども観・発達観」に基づき、この子ど もの発達する可能性を活かすために 3 つの教育の原則」 が提案された。活動の主体は子どもであるとされ、子ど もの発達にとって適切な環境を整えることが重要である とされた。環境は「人的環境」と「物理的環境」とに区 別され、「人的環境」である教師には消極的であることが 求められ、特に重視されたのが「物理的環境」であるこ とが大きな特徴であった。「物理的環境」こそが、子ども の自律的活動を喚起・援助するとされ、このような物理 的環境が持つべき「8つの性質」が提案された。

\section{（2）物理的環境の性質と具体的な特徴}

モンテッソーリ教育では、子どもの自律的活動を喚起・ 援助するために、「物理的環境」は「8つの性質」（図 1 参 照）を持つことが望ましいとされたと考えられた。これ らの「8つの性質」は、モンテッソーリの「子ども観・発 達観」に基づき、子どもが発達のために必要とする環境 との相互交渉をよりよく行うための性質であると言える。

モンテッソーリは著作において、物理的環境の具体的 な特徴を記述していたが、これはモンテッソーリ自身が ローマの「子どもの家」で実践した一例として理解す心゙ きだと考えられた。すなわち、「子どもの家」の物理的環 境は、物理的環境の持つべき「8つの性質」を満たしてい れば、それぞれの財政状況、保育時間、空間的な制約そ して何より、文化に応じて設定すればよいとされた。モ
ンテッソーリの物理的環境の具体的な記述から学ぶべき ことは、園舎から子どもが使用する小さな道具に至るま で、すべてを物理的環境として考慮し、整えるというこ とだと考えられる。これは、モンテッソーリが物理的環 境を子どもが自由に選択し、使用するもの全体として考 慮しなければならないとしたことを、反映していると言 えるだろう。

（3）モンテッソーリの教育理念と物理的環境の重視

モンテッソーリは、子どもは生まれながらの発達の法 則・計画に基づき自律的に活動し、環境と相互交涉する ことで発達するとし、子どもの自律的活動を尊重するた めに活動の主体は子じもだとした。モンテッソーリは環 境を「人的環境」と「物理的環境」の 2 つに分けて考え ていた。

「人的環境」である教師は子どもの自律的活動を妨げる 大きな障害になる可能性があるとし、教師は消極的であ るべきだとされた。従来の教育のように教師が子どもの 活動を喚起するのであれば、教育の主導権を教師がとっ てしまい、子どもは自らの発達の計画に基づき自律的に 活動することが難しくなる。これに対して、物理的環境 は活動を動機づけるものの、子どもに一方的に活動を強 いることはなく、子どもが主体となり、自分の発達の段 階に合わせて、必要な活動を選択することができると考 えられる。また、教師ではなく、物理的環境がフィード バックを与えることで、子どもは必要とするフィードバッ クのみを受け取り、誤りに気づき、主体的に学ぶことが できる。

このように、子どもを活動の主体とするためには、子 どもの活動を喚起・援助するのは、「人的環境」よりも「物 理的環境」の方が適切だと考えられ、そのためにモンテッ ソーリは「物理的環境」を重視したのだと思われる。そ して、子どもが環境との相互交渉をよりよく行うために、 モンテッソーリは自身の「子ども観・発達観」に基づき、 物理的環境の「8つの性質」を提案したと考えられた。

\section{2 考察}

以上の分析結果に基づき、子どものための物理的環境 に関する以下の 3 点を考察する。

\subsection{1 教育法と物理的環境}

モンテッソーリが物理的環境が満たすべきとした「8つ の性質」とは、モンテッソーリの「子ども観・発達観」 にもとづき、子どもを活動の主体とし、その自律的活動 を尊重するための「教育の原則」を実現するために、物 理的環境の設定において考慮す心゙きだとした性質である。 その設定は各幼児教育施設の財政状況、保育時間、文化 によって変わりうる、つまり、どのように実現するかは 各施設の状況に合わせて行っていいとしたものの、「8つ の性質」は考慮することが求められたのである。言い換 えれば、モンテッソーリは、幼児教育施設の物理的環境は、 そこで実践される教育法の「子ども観・発達観」および「教 
育の原則」に基づくことを重視していたと考えられる。

わが国の文部科学省や厚生労働省による幼児教育の指 針一『幼稚園教育要領』（文部科学省, 2008）と『保育所 保育指針』（厚生労働省，2008）一でも、「環境による教育」 が基本だとされているが（渡辺，2009）、物理的環境の整 え方の具体的な手法には手がつけられてはいない。もっ とも避けなければならいのは、物理的環境が適切でない ために、教育内容を変更したり、断念せざるを得なくな るということである。

幼児教育施設の設計・設定は、その施設で実践される 教育法がどのようなものであるかを抜きにはできないこ とを、モンテッソーリは強調している。モンテッソーリ の「子ども観・発達観」および「教育の原則」を反映し た建築、設備、家具、道具などへの細かい配慮の仕方は、 幼児教育施設における物理的環境の整え方を模索する上 で、学ぶべき点が多いといえよう。

\section{2 .2 子どもの尊重と物理的環境}

「8つの性質」は、モンテッソーリの「子ども観・発達観」 と、それに基づいた「教育の原則」を実現するために提 案された。さらに、モンテッソーリ教育における活動の 主体は、子どもであることが強調された。つまり、それは、 「子どもの家」の主たるユーザーは、子どもであることを 意味している。「子どもの家」の物理的環境は、主たるユー ザーである子どもの自律的な活動と発達に最適な環境で あるよう考慮された環境であるとも言える。

「子どもサイズ」を例にとっても、モンテッソーリは単 に子どもの体格に合った寸法にすることにとじまらず、 子どもの体力、理解力をも考慮する必要があるとした。 さらに、子どもが発達の法則・計画に従って発達すると はどういうことか、発達の各段階で何を必要とするのか、 発達するためには集中して活動することが必要であるこ となら゙、子どもの精神的特徵、さらには発達の特徴まで をも考え抜き、子どもに適切な物理的環境の性質を提案 しているのである。

モンテッソーリの提案とは、子どもを尊重する幼児教 育施設は、教育の理念を実現するためにだけ設定するの ではなく、活動の主体であり、施設の主たるユーザーで ある子どもを尊重するためにも設定されなければならな いということである。そのためには、単に子どもの体格 に合わせた寸法にするだけではなく、子どもの身体的、 精神的、発達の特徵などを多角的に考慮し、深く理解し、 子どもを尊重するとはどういうことなのか考えなければ ならない。モンテッソーリは、物理的環境において子ど もを尊重するとはどのようなことなのか、明確に示して いると思われる。

\section{2 .3 物理的環境の質・豊かさと機能性}

モンテッソーリの物理的環境が持つべき「8つの性質」 の中には、物理的環境の質、美しさ、豊かさ、魅力など が含まれていることも注目される。

まず、モンテッソーリは物理的環境の美しさや魅力、
本物であることは子どもの活動の動機づけになる (性質 4、 7）とした。認知科学者の Norman（2004）は情動システ ムが認知システムに影響を与えることから、美的に魅力 的なものはポジティブな情動を生み、学習や好奇心、創 造的な思考を促進すると指摘している。これは、モンテッ ソーリの考えと一致する。

さらにモンテッソーリは、子どもというユーザーを真 に尊重する物理的環境とは、機能的に優れているだけで はなく、大人が生活する環境と同様に魅力的で豊かな環 境であることが必要である(性質 8) とも考えていた。実際、 $1920 \sim 30$ 年代の「子どもの家」では、国際的に近代デザ インを铎引していた造形学校であるバウハウスにおいて デザインされた食器を揃えたり (Kramer, 1976/1981/1988)、 バウハウスの卒業生がウィーンのモンテッソーリ幼稚園 の園舎の室内デザインを任され、豊かで魅力的な物理的 環境を実現させた例がみられる（高橋, 2008; 高橋・元岡, 2009)。

\section{3 今後の課題}

本研究では、モンテッソーリの著作 12 点を分析対象と した。分析対象とした著作は、モンテッソーリによるモ ンテッソーリ教育に関する最初の著作、 3 大著作、最後 の著作、そして物理的環境に関する記述が多い著作 7 点 であった。分析対象の著作の選定段階では、現在入手可 能な内外のモンテッソーリの著作のほとんどに目を通し、 上記のような条件を満たす著作を慎重に選定したつもり である。しかし、モンテッソーリは世界各国でモンテッ ソーリ教育の普及に尽くしたため、様々な国で講演し、 教師養成コースを開催し、それに加えて各国で新聞に記 事を連載したり、論文を発表している。そのため、分析 対象とした著作以外にも、物理的環境に関する記述が残 されている可能性はあり得る。今後の分析を進展させる ためには、さらなる資料の入手は大きな課題である。

本研究の分析により、幼児教育施設の物理的環境はそ こで実践される教育法と切り離しては考えられないこと が示唆された。今後はモンテッソーリ教育を実践する園 舎において、物理的環境がどのように実現されているの か、園舎の実例の分析により明らかにしていきたい。

さらには、モンテッソーリは物理的環境が子どもの自 律的活動を喚起・援助することを意図していたことから、 それが実際にはどのようなことかを検討する必要がある。 たとえば、モンテッソーリの教育理念を実現するべく設 計・設定された建築、設備、家具、道具などが、実際に どのように子どもの活動を喚起・援助するのか、環境と 子どもとの相互交渉がどのようにおこるのかを、子どもの 行動観察によって明らかにしたいと考えている。

\section{謝辞}

本研究は、2014 年 3 月にお茶の水女子大学に受理され た博士学位論文の一部に、加筆、修正したものである。 博士学位論文についてご指導いただいた、お茶の水女子 大学大学院人間文化創成科学研究科の元岡展久准教授に 
感謝する。

\section{注}

(1) お茶の水女子大学附属図書館所蔵の 1912 年出版の The Montessori Method の Acknowledgments には、英 語版を出版するにあたり、モンテッソーリ自身が大 幅に加筆、修正したとの記述が見られる。なお、本 論文の分析で主に使用した The Montessori Method は、 1964 年に再版されたものである。1964 年版ではこの Acknowledgments は省略されている。

\section{引用文献}

Burke, C. \& Grosvenor, I. (2008). School. London: Reaktion Books.

Dewey, J. (1900/1902/1915/1990). The School and Society and the Child and the Curriculum. Chicago: the University of Chicago Press.（デューイ, J., 宮原誠一（訳）（1957）. 学校と社会. 岩波書店.)

Dudek, M. (2000). Kindergarten Architecture: Space for the imagination (2nd ed.). London: Spon Press.

Foschi, R. (2008). Science and culture around the Montessori's first "Children's Houses" in Rome (1907-1915). Journal of the History of the Behavioral Sciences, 44(3), 238-257.

波多野誼余夫・稲垣佳世子 (1973). 知的好奇心. 中公新書. 早田由美子 (2003)。モンテッソーリ教育思想の形成過程 一「知的生命」の援助をめぐって一. 勁草書房.

東谷孝一 (2007)。モンテッソーリ教育の研究（3）。東筑 紫短期大学研究紀要, 38, 139-146.

稲垣佳世子・波多野誼余夫（1989）。人はいかに学ぶか一 日常的認知の世界一. 中公新書.

神成健・初見学 (1984). モンテッソーリ教育と幼稚園の 計画一オープンエジュケーションと幼稚園の計画に関 する研究一. 日本建築学会関東支部研究報告集（計画 系), 55, 281-284.

甲斐仁子 (1985)。モンテッソーリ教育学における「環境」 の意味するもの.モンテッソーリ教育, 18, 20-29.

甲斐仁子（1995）。モンテッソリ教育環境の多様性一哲学 的考察一. 九州教育学会研究紀要, 23, 289-295.

甲斐仁子 (1997)。モンテッソーリ教育環境一社会的変容 と再考一. モンテッソーリ教育, 30, 80-89.

厚生労働省（編）（2008）。保育所保育指針解説書. フレー ベル館.

Kramer, R. (1976/1988). Maria Montessori: A biography. Boston: Da Capo Press. (クレーマーR., 平井久（監訳), 三 谷嘉明・佐藤敬子・村瀬亜理（訳）（1981）。マリア・ モンテッソーリ 子どもへの愛と生涯. 新曜社.）

文部科学省 (2008). 幼稚園教育要領解説. フレーベル館.

Montessori, M. (1909). Il metodo della pedagogia scientifica applicato all'educazione infantile nelle case dei bambini. Roma: Max Bretschneider.

Montessori, M. (1912). The Montessori Method: scientific pedagogy as applied to child education in "the children's houses" with additions and revisions by the author (A. E. George, Trans.). New York, NY: Frederick A. Stokes Company.

Montessori, M. (1964). The Montessori method with an introduction by J. McV. Hunt (A. E. George, Trans.). New York, NY: Schocken Books.

モンテッソーリ M., 阿部真美子・白川蓉子（訳）（1974）. モンテッソーリ・メソッド. 明治図書.

モンテッソーリ M., プラカサム A. G. (編), 鈴木弘美（訳） (1993). 子供の何を知るべきか一モンテッソーリの教 育一.エンデルレ書店. (Montessori, M., Prakasam, A. G., (Ed.). (1989f). The Clio Montessori series: Vol.4. What you should know about your child. Oxford: Clio Press.)

Montessori, M. (1999a). Il segreto dell'infanzia. Milano: Garzanti.

Montessori, M. (1999c). La scoperta del bambino. Milano: Garzanti.

Mooney, C. G. (2000). Theories of childhood: An introduction to Dewey, Montessori, Erikson, Piaget, and Vygotsky. St. Paul, MN: Redleaf Press.

Müller, T., \& Schneider, R. (Eds.). (2002). Montessori Lehrmaterialien 1913-1935 Möbel und Architektur/ Montessori Teaching Materials 1913-1935 Furniture and Architecture (C. Charlesworth, Translated from the German). München: Prestel.

長沢悟・深堀千鶴（1988）。自由保育幼稚園の保育空間の 構成に関する研究: モンテッソリ幼稚園を通して. 日 本建築学会大会学術講演梗概集 E（建築計画・農村計 画), 381-382.

中野光・小笠毅（編）（1996）。ハンドブック子どもの権 利条約. 岩波ジュニア新書.

日本建築学会（編）（2005）。第 3 版 コンパクト建築設計 資料集成. 丸善出版.

ノーマン D. A., 岡本明 - 安村通晃 ・ 伊賀聡一郎 ・ 上野晶子 （訳）（2004）。エモーショナル・デザイン一微笑を誘う モノたちのために一。 新曜社. (Norman, D. A. (2004). Emotional design: Why we love (or hate) everyday things. New York, NY: Basic Books.)

小川洋司 (1985)。保育園・幼稚園の設計一その実例に即 して一。建築思潮研究所 (編), 建築設計資料 10 保育園・ 幼稚園 (pp. 4-32)。建築資料研究社.

Peller, L. E. (1996). The children's house. The NAMTA Journal, 21(3), 8-23. (Reprinted from On development and education of young children: Selected papers, by E. N. Plank, Ed., 1978, New York, NY: The Philosophical Library.)

Standing, E. M. (1957/1998). Maria Montessori: Her Life and Work. New York, NY: Plume. (スタンディング E. M., ルー メル K. (監修)，佐藤幸江（訳）（1975）。モンテソー リの発見一人間らしく育つ権利一. エンデルレ書店. )

高橋節子 (2008). 子どものための建築空間—モンテッソー リ教育のための園舎の場合一. 日本建築学会大会学術 講演梗概集 F2（建築歴史・意匠），611-612.

高橋節子・元岡展久 (2009). 子どものための建築空間— ウィーンのモンテッソーリ保育園の場合一。 日本建築 
学会大会学術講演梗概集 F2（建築歴史・意匠），121122.

天満類子・菊地成朋 (2004). 幼児保育における「場」の 環境形成に関する事例研究—モンテッソーリ教育を実 践する幼稚園の記録一. 都市・建築学研究（九州大学 大学院人間環境学研究院紀要), 6, 65-76.

鼓常良（1968）。紹介一マリーア・モンテッソーリとその 事業一. M. モンテッソーリ，鼓常良（訳），幼児の秘 密（pp. 253-258）, 国土社.

渡辺英則 (2009)。保育の環境. 森上史朗・大豆生田啓友 (編)，よくわかる保育原理 第 2 版 (pp. 102-103)。ミネ ルヴァ書房.

付録

本研究で分析したモンテッソーリの著作一覧

(1) モンテッソーリ・メソッド

(1909). Il metodo della pedagogia scientifica applicato all'educazione infantile nelle case dei bambini. Roma: Max Bretschneider.

(1964). The Montessori method with an introduction by J. McV. Hunt (A. E. George, Trans.). New York, NY: Schocken Books.

阿部真美子・白川蓉子 (訳) (1974)。モンテッソーリ・メソッ ド。明治図書。

(2)幼児の秘密

(1999a). Il segreto dell'infanzia. Milano: Garzanti.

(1972a). The secret of childhood (M. J. Costelloe, Trans.). New York, NY: Ballantine Books.

鼓常良（訳）（1968）。幼児の秘密. 国土社.

(3) 創造する子供

(1999b). La mente del bambino. Milano: Garzanti.

(1967). The absorbent mind (C. A. Claremont, Trans.). New York, NY: Henry Holt and Company.

菊野正隆（監修）, 武田正實（訳）（1973）。創造する子供. エンデルレ書店.

(4)子どもの発見

(1999c). La scoperta del bambino. Milano: Garzanti.

(1972b). The discovery of the child (M. J. Costelloe, Trans.). New York, NY: The Random House Publishing Group.

鼓常良（訳）（1971a）。子どもの発見. 国土社.

(5) 人間の形成について

(1989a). The Clio Montessori series: Vol.3. The formation of man (A. M. Joosten, Trans.). Oxford: Clio Press.

坂本堯（訳）（1970a)。人間の形成について. エンデルレ 書店.

(6) 私のハンドブック

(2005). Dr. Montessori's own handbook. New York, NY: Dover. 平野智美・渡辺起世子（訳）（1989b）。私のハンドブック。 エンデルレ書店.

(7) モンテッソーリ教育の実践理論

Buchenmeyer, R. G. (Ed.). (1997). The Clio Montessori series: Vol.15. The California lectures of Maria Montessori, 1915:
Collected speeches and writings. Oxford: Clio Press.

バッケンマイヤー R. G. (編), ルーメル K.・江島正子（訳）

(2010). モンテッソーリ教育の実践理論一カリフォル

ニア・レクチュアー。サンパウロ

(8) 幼児と家庭

(1989c). The Clio Montessori series: Vol.8. The child in the family (N. R. Cirillo, Trans.). Oxford: Clio Press.

日本モンテッソーリ協会（監修), 鷹觜達衛（訳）（1971b）. 幼児と家庭. エンデルレ書店.

(9) モンテッソーリの教育法 : 基礎理論

(1965). Grundlagen meiner Pädagogik. Wiebelsheim: Quelle \& Meyer.

ルーメル K.・江島正子（訳）（1983）。モンテッソーリの 教育法一基礎理論一. エンデルレ書店.

(10) 子どもと学校の危機

Schulz-Benesch, G. (Ed.). (1989c). The Clio Montessori series: Vol.7. The child, society and the world: unpublished speeches and writings (C. Juler \& H. Yesson, Trans.). Oxford: Clio Press.

シュルツ＝ベネシュ G.（編)，ルーメル K.・江島正子（訳） (1982). 子どもと学校の危機一社会・学校・世界一. エンデルレ書店.

(11) モンテッソーリの教育 : ○歳〜六歳まで

(1989e). The Clio Montessori series: Vol.5. Education for a new world. Oxford: Clio Press.

吉本二郎・林信二郎（訳）（1970b）。モンテッソーリの教 育一○歳〜六歳まで一，あすなろ書房.

(12) 子供の何を知るべきか

Prakasam, A. G. (Ed.). (1989f). The Clio Montessori series: Vol.4. What you should know about your child. Oxford: Clio Press.

プラカサム A. G.（編），鈴木弘美（訳）（1993）。尒供の何 を知るべきか一モンテッソーリの教育—. エンデルレ 書店.

(受稿 : 2014 年 12 月 22 日 受理 : 2015 年 3 月 11 日) 